\title{
An Empirical Study of the Relationship between Entrepreneurial Curiosity and Innovativeness
}

\author{
Žiga Peljko', Mitja Jeraj², Gheorghe Săvoiư ${ }^{3}$, Miha Marič ${ }^{4}$ \\ ${ }^{1}$ KD Group d.d., Ljubljana, Slovenia \\ ziga.peljko@kd-group.si \\ ${ }^{2}$ GEA College, Faculty of Entrepreneurship, Ljubljana, Slovenia \\ mitja.jeraj@gea-college.si \\ ${ }^{3}$ University of Pitesti, Faculty of Economic Sciences, Romania \\ gheorghe.savoiu@upit.ro \\ ${ }^{4}$ University of Maribor, Faculty of Organizational Sciences, Slovenia \\ miha.maric@fov.uni-mb.si (corresponding author)
}

\begin{abstract}
Background and Purpose: Despite scholarly interest in understanding the role of different determinants on entrepreneurs and their behavior, little is known about the relationship between entrepreneurial curiosity and innovativeness. This research explores the relationship between entrepreneurial curiosity, which motivates entrepreneurs to gather information about their business and innovativeness that motivate entrepreneurs to incorporate innovations into entrepreneurial processes.

Design/Methodology/Approach: Participants in this study were entrepreneurs from Slovenia and USA. By using structural equation modelling, we linked the two constructs of entrepreneurial curiosity and innovativeness to test the influence.

Results: Results indicate that entrepreneurial curiosity positively influences innovativeness. The results of this study indicate that at the frame of entrepreneurship psychology entrepreneurial curiosity is important for innovativeness.

Conclusion: This paper links the two studied constructs and presents a valuable contribution for entrepreneurship theory; therefore, the results could be used for a further scientific research as also for practical implications.
\end{abstract}

Keywords: Entrepreneurial Curiosity, Innovativeness, Company, Entrepreneurship, Entrepreneur

\section{Introduction}

The nexus of entrepreneurship, innovation and sustainable development is a subject of great interest nowadays, as society is looking for solutions leading to sustainable development (Kardos, 2012). This paper studies the relationship between entrepreneurial curiosity as a determinant which influences entrepreneurs and innovativeness as an important part of economic dynamism. Understanding entrepreneurial cognition is imperative to understanding the essence of entrepreneurship, how it emerges and evolves (Krueger, 2003). Entrepreneurs' innovativeness and personality play a key role in the adoption of innovations in Small- and Medium-sized Enterprises (SMEs) (Marcati, 2008).

There is no consensus on how to define the entrepreneur in the economics literature (Ünay and Zehir, 2012). Since SMEs are a key source of innovation and economic growth (Schelmelter, 2010) the entrepreneurs who answered the survey can give us up to date data about situation in their organizations and on the market. Entrepreneurs are the key 
factors of entrepreneurship, which contributes to the quality and future hopes of a sector, economy or even a Country, where the role of the entrepreneurs is crucial in creating value (Huarng and Ribeiro-Soriano, 2014). Current multi-country empirical research was conducted among SMEs in Slovenia and USA. Surveys were sent to entrepreneurs; the founders or the owners of the company to where the survey was sent. The values and orientations of firms thus differ between those who actively search for new solutions and those who maintain a more inward-looking or possibly downstream focus on innovation processes: incremental innovations are often associated with a focus on existing customers (Grundström et al., 2012). In this research, the focus was oriented towards innovative entrepreneurs who actively try to improve their work, their products / services, try to sell new things on the steady way or to sell steady products / services based on modern approaches.

Human action has many roots, yet most researchers - even most philosophers - would argue that decision precedes action (Audi, 1993; Kosec and Miglič, 2012). Entrepreneurs are acting on the base of many factors and determinants, internal and external. This paper investigates how entrepreneurial curiosity influence on innovativeness among entrepreneurs in Slovenia and USA. Thus, the origin of entrepreneurial curiosity seems to have some common points with innovativeness; these constructs deal with the modern type of entrepreneurs who want to expand business and improve their business results. The dynamics of disequilibrium and market disruption postulate that continuous innovation serves as a vital role for firms to gain sustainable competitiveness in a dynamic environment ( $\mathrm{Yu}$ et al., 2013) and the entrepreneurs are the main source of energy for involving the innovative approaches into the business and into economy as a whole system.

The primary aim of the paper was to reveal a connection between entrepreneurial curiosity and innovativeness among the entrepreneurs. Following Fairlie and Holleran (2012) who wrote that promoting entrepreneurship is viewed as a national priority by governments around the world; an additional aim of the paper is to promote entrepreneurship in order to present it to the broader audiences. Entrepreneurship is the main generator of the new jobs and the fundamental reason for the sustainable development.

Based on Kardos (2012) the relationship between entrepreneurship and sustainable development has been addressed by various streams of thought and literature such as:

- Entrepreneurship, environmentally orientated entrepreneurship;

- social entrepreneurship - entrepreneurship that aims to provide innovative solutions to unsolved social problems OECD (2010);

- institutional entrepreneurship, contributing to change regulatory, societal and market institutions, responsible entrepreneurship - a term coined by the UN
Environmental Program in the context of Agenda 21, meaning "healthy" entrepreneurial business, which joining economic, technological, environmental factors is or must be responsible to society, enhancing the business positive contribution to society whilst minimizing negative impacts on people and the environment responsible entrepreneurship.

Today, the role of innovation and market orientation has turned into an important competitive tool to sustain competitive advantage and survive in the global competitive market (Dess and Picken, 2000; Tushman and O'Reilly, 1996; Crossan and Apaydin, 2010, Candemir and Zalluhoğlu, 2013). Therefore, it is not surprising that innovations and entrepreneurs are one of the main research topics lately in scientific and also nonscientific literature. The terms radical, really new, incremental and discontinuous are used ubiquitously to identify innovations (Garcia and Calantone, 2002).

Many authors define relationship between the innovation as the process and the output of that process (e.g. Tidd and Bessant, 2011). Literature review of scientific documentation revealed that innovativeness was connected to:

- firm performance (Craig et al., 2013);

- according to Schumpeter, innovation is reflected in novel outputs: a new good or a new quality of a good; a new method of production; a new market; a new source of supply; or a new organizational structure, which can be summarized as 'doing things differently' (Crossan and Apaydin, 2010);

- Dibrell et al. (2013) revealed in their study that firms' formal strategic planning processes and planning flexibility are positively associated, and each is positively related to innovativeness;

- innovation is the single business activity that most closely relates to economic growth (Soriano and Huarng, 2013) etc.

On the other site entrepreneurial curiosity was connected to entrepreneurial self-efficacy (Jeraj and Marič, 2013a); to openness and firm growth (Jeraj, 2014). Since both researched constructs in this paper, entrepreneurial curiosity and innovativeness are important elements of entrepreneurship and both were connected to other entrepreneurship parts. The relation of entrepreneurial curiosity to innovativeness till this study remained unexplored.

\section{Entrepreneurial Curiosity}

Literature review from the field of entrepreneurship, psychology, organizational sciences, sociology etc. revealed that researchers have an interest to study the psychology of entrepreneurs: e.g. cognitive psychology of entrepreneurship (perception, intention, belief structures etc.) (Krueger, 2003); entrepreneurs' dispositional positive affect (Baron 
et al., 2012); person-entrepreneurship fit (Markman and Baron, 2003); entrepreneurial intuition (Blume and Covin, 2011); and others.

Interesting determinant influencing entrepreneurs is also entrepreneurial curiosity. According to Jeraj and Antončič (2013) the entrepreneurial curiosity construct and measure were developed in line with the steps recommended by Churchill (1979), Dawis (1987), DeVellis (2003), Gerbing and Anderson (1988), and Hinkin (1995). Entrepreneurial curiosity is defined as a positive emotional/motivational system oriented toward investigation in the entrepreneurial framework to learn tasks related to entrepreneurship and incorporate new experiences in order to improve business (Jeraj, 2012; Jeraj and Antončič, 2013; Jeraj and Marič, 2013b).

Entrepreneurial curiosity is an interest in novelties or observations of society and a tendency to search for answers that indicate which demands should be met and it also represents guidance and competitive advantages for entrepreneurs relative to the competition (Jeraj and Marič, 2013a). Entrepreneurial curiosity is awake, when an entrepreneur is facing different stimulus related to the entrepreneurship in the environment (Jeraj and Prodan 2010). Since this construct deals with different essential elements of entrepreneurship (e.g. market research, analysis of the competition, innovations, gathering important information and data, etc.) a relatively high level of entrepreneurial curiosity can represent value added in comparison to the entrepreneurs that have entrepreneurial curiosity on relatively low level.

Organizations (or, for that matter, communities) need to provide and develop a "cognitive infrastructure" that nurtures entrepreneurial thinking (Krueger, 2003). Thus entrepreneurial curiosity is a powerful engine in generation of business ideas and curious entrepreneurs obtain appropriate data and make decisions based on them (Jeraj, 2012). Further, some scholars have argued that entrepreneurial learning helps entrepreneurs develop their skills and knowledge, and so enhances their future performance (Cope, 2005; Rae and Carswell, 2000, Parker, 2013). According to $\mathrm{Yu}$ et al. (2013), the integration of knowledge and resources can reduce organizational inertia and strengthen a firm's innovativeness. Since Garcia and Calantone (2002) defined innovativeness as an iterative process initiated by the perception of a new market and/or new service opportunity for a technology based invention which leads to development, production, and marketing tasks striving for the commercial success of the invention it is necessary to empirically test connection between entrepreneurial curiosity and innovativeness.

\section{Innovativeness}

Innovation is the ". . process that turns an invention ... into a marketable product” (Gabor 1970).

Among the many drivers of innovation, researchers have paid a growing attention to the internal factors leading to innovative behaviors by individuals (Marcati et al., 2008) where entrepreneurial orientation represent a strategic state of the company. Innovation is therefore more than invention; it also involves the commercialization of ideas, implementation, and the modification of existing products, systems and resources (Bird, 1989). Innovation matters, not only at the level of the individual enterprise but also increasingly as the wellspring for national economic growth (Tidd and Bessant, 2011).

Garcia and Calantone (2002) defined innovation as an iterative process initiated by the perception of a new market and / or new service opportunity for a technology based invention which leads to development, production, and marketing tasks striving for the commercial success of the invention.

Tidd and Bessant (2011) further operationalized key characteristics of innovation as:

- Degree of novelty - incremental or radical innovation?

- Platforms and families of innovations.

- Discontinuous innovation - what happens when the rules of the game change?

- Level of the innovation - component or architecture?

- Timing - the innovation life cycle.

For higher growth of the company, it is necessary to become entrepreneurial oriented. Based on Dai et al. (2013) entrepreneurial orientation refers to a set of behaviors namely innovativeness, proactiveness, and risk-taking that have been found to influence international learning (De Clercq et al., 2005), speed of entry (Zhou, 2007), and performance (Zhang et al., 2012). There appears to be strong empirical evidence to support the claim that entrepreneurs, particularly those successful at growing an enterprise, are more innovative than non-entrepreneurs (Mueller and Thomas, 2001).

Due to fierce competition in the marketplace, globalization and an explosion of technology in recent years, innovation and differentiation are considered as a necessity for every company (Tajeddini and Trueman, 2008). On the one hand innovativeness can, and does, vary in complexity, ranging from changes to existing products, processes or services to the introduction of new breakthrough technologies that introduce first-time features, offer exceptional performance, or change the rules of the competitive domain (Craig et al., 2013) while on the other hand some innovation scholars argue that innovation types are artificial distinctions and that they are conceptually and operation- 
ally alike (Edquist et al., 2001). In this study the concept of the innovation is perceived as a personal judgment of the entrepreneur about the level of his innovativeness.

\section{Entrepreneurial curiosity and inno- vativeness}

Based to Mueller and Thomas (2001) in describing entrepreneurs, Joseph Schumpeter noted that these were the individuals who attempted to "...reform or revolutionize the pattern of production by exploiting an invention... or untried technical possibility for producing a new commodity or producing an old one in a new way... [This] requires aptitudes that are present in only a small fraction of the population..." (Schumpeter 1934). Therefore, entrepreneurship and innovation can be viewed as different sides of the same coin (Soriano and Huarng, 2013).

According to Ünay and Zehir (2012) over the course of economic globalization, the innovation aspect of entrepreneurship has gained critical importance in almost all sectors. Firms that score high on entrepreneurial orientation are believed to be engaged in innovation frequently, to be more willing to take risks and to act more proactively when opportunities arise (Rezaei et al., 2012).

Operationally, organizational innovativeness development is associated with knowledge and resources that can carry strategic orientations to innovation (Yu et al., 2013). Entrepreneurial orientation reflects a firm's innovativeness, proactiveness, and willingness to undertake risks (Lumpkin and Dess, 1996). Sanchez-Franco and Roldán (2010) summarized that innovative people tend to seek out new, mental or sensual experiences (cf. Venkatraman 1991; Uray \& Dedeoglu, 1997):

- (a) orienting their curiosity towards stimulating design,

- (b) making evaluations as to whether virtual services fulfil their initial experiential expectations, and

- (c) fostering users to stay.

Based on written above it could be predicted that curiosity, among other things influences innovativeness. Similar connection was perceived by Jeraj and Antončič (2013) who stressed that motivated individuals with a relatively high level of entrepreneurial curiosity could be involved in the entrepreneurial process and contribute to the innovativeness and growth of the company.

Deniz and Godekmerdan (2012) wrote innovativeness integrates problem solver, profit oriented $R \& D$, curiosity oriented research, and further entrepreneurial curiosity is a powerful generator of business ideas (Jeraj and Antončič, 2013). Innovativeness involves the ability of the firm to promote new and creative ideas, products and processes designed to service the market (Lumpkin and Dess, 1996).

Innovation is essentially about change and it is often disruptive, risky and costly (Türker and İnel, 2012) that is why entrepreneurs must have some specific knowledge to make appropriate decisions. Innovativeness can be defined as "the notion of openness to new ideas as an aspect of a firm's culture" (Hurley and Hult, 1998). Since research of Jeraj (2014) show openness is connected to entrepreneurial curiosity and entrepreneurial curiosity influence company's growth as also innovativeness (e.g. Craig et al., 2013) and based on the theoretical predispositions that suggest entrepreneurial curiosity and innovativeness are connected the following hypothesis was formulated: "Entrepreneurial Curiosity positively influences Innovativeness."

\section{Method}

\subsection{Sample and data collection process}

The sample consisted from randomly selected entrepreneurs from Slovenia and USA. The email addresses were collect from free online databases and the surveys were sent to 4,000 Slovenian entrepreneurs in Slovenian language and to 5,000 USA entrepreneurs in English. An average time for completing the survey was approximately 10 minutes.

The survey consisted from measures of entrepreneurial curiosity, innovativeness, some demographic questions, and questions about some parameters of their companies. 331 entrepreneurs responded from both countries and all answers were appropriate for statistical analysis since the online survey was programed in the way where was impossible to continue without answering all questions in the current page.

Multi-country sample consisted of 237 (71.6\%) male and $93(28.1 \%)$ female respondents ( 1 person undefined). $47.7 \%$ of entrepreneurs were Slovenians and 52.3\% Americans. Regarding to the respondents' companies by sector the most entrepreneurs came from management and consulting business services $(12,4 \%)$, then construction sector $(11,5 \%)$, retail or wholesale trade $(10,9 \%)$, manufacturing industrial goods $(9,4 \%)$, banking, investment, insurance $(8,8 \%)$, and others.

An analysis of the age of companies show that most companies included in our survey were from 11 to 20 years old $(34,4 \%)$, then from 21 to 50 years old $(30,5 \%)$, from 6 to 10 years old $(13 \%)$, from 2 to 5 years old $(11,2 \%)$, more than 50 years old $(10 \%)$, and as the least class less than 1 year old $(1,5 \%) .78,5 \%$ of entrepreneurs were at least once in a life employed in the company that was not theirs.

\subsection{Description of measures}

Innovativeness was measured using the Jackson Personality Inventory, which Mueller and Thomas (2001) adopted 
Table 1: Innovativeness measure (*These items were reverse scored before scoring and analysis.)

\begin{tabular}{|l|l|}
\hline \multicolumn{2}{|c|}{ INNOVATIVENESS } \\
\hline $\mathbf{1 .}$ & I often surprise people with my novel ideas. \\
\hline $\mathbf{2 .}$ & People often ask me for help in creative activities. \\
\hline $\mathbf{3 .}$ & I obtain more satisfaction from mastering a skill than coming up with a new idea. ${ }^{*}$ \\
\hline $\mathbf{4 .}$ & I prefer work that requires original thinking. \\
\hline $\mathbf{5 .}$ & I usually continue doing a new job in exactly the way it was taught to me. ${ }^{*}$ \\
\hline $\mathbf{6 .}$ & I like a job which demands skill and practice rather than inventiveness. ${ }^{*}$ \\
\hline $\mathbf{7 .}$ & I am not a very creative person. ${ }^{*}$ \\
\hline $\mathbf{8 .}$ & I like to experiment with various ways of doing the same thing. \\
\hline
\end{tabular}

Table 2: Entrepreneurial Curiosity measure

\section{ENTREPRENEURIAL CURIOSITY}

1. While doing market research, I focus on the work so much that I lose track of time.

2. When I notice an abandoned building, I think about what business potential it represents for me.

3. It bores me to always watch the same products; therefore, I think about improving and offering them to the market.

4. I explore new things that could create additional profit.

5. I am interested in other entrepreneurs' interests.

6. In entrepreneurial work, I am mostly interested in competition.

7. In my business, I must have information about marketing that is as complete as possible.

8. I am able to create added value from my observations of the environment.

from (Jackson 1994). The Jackson Personality Inventory Manual (JPI), which defines innovativeness as a tendency to be creative in thought and action, was used to capture this construct as innovation, creativity, and initiative have been consistently identified as one of the enduring characteristics of entrepreneurs (Mueller and Thomas, 2001). Entrepreneurs were asked to indicate the extent of their agreement with each of the items; how strongly they agree or disagree with the statement on a fifth level Likert's scale (1974). Eight items comprise the Innovativeness (Table 1) scale.

Entrepreneurial Curiosity measure Jeraj (2014) was composed from the Pre-Entrepreneurial curiosity and Entrepreneurial curiosity measure. Entrepreneurs had to indicate for each of the statements related to entrepreneurial curiosity how often does a particular activity occur in their life by circling the number of frequency of the occurrence from " 1 " - the activity never occurs to " 7 " - it always occurs for first three items and how strongly they personally agree or disagree with the statement. " 1 " indicated that they strongly disagree, and " 7 " indicated that they strongly agree with the statement for the last four items. According to factor analysis the lowest factor loading in Entrepreneurial curiosity measure (Table 2 ) was just above 0.4 and the highest factor loading was 0.8 .

\section{Results}

Exploratory factor analysis (EFA) is used to "identify the factor structure or model for a set of variables" (Bandalos, 1996). Exploratory factor analysis was conducted for both, the Slovenian sample and the US sample together. In terms of factors, the results of the factor analysis were similar for the Slovenian and USA samples.

Structural equation modeling (SEM) provides a way to test the specified set of relationships among observed and latent variables as a whole, and allow theory testing even when experiments are not possible (Savalei and Bentler, 2010). Structural equation modeling was made by building a model in Lisrel 8.80, which is an analytical statistics program. Results of structural equation modeling based on the joint sample from Slovenia and USA $(n=331)$ are displayed in Figure 1.

For the purpose of estimating results of multi-country empirical validation was used a combination of exploratory (EFA) and confirmatory methods (CFA - all the variables were included to the structural equation model) with the goal to develop a model which complement theoretical 


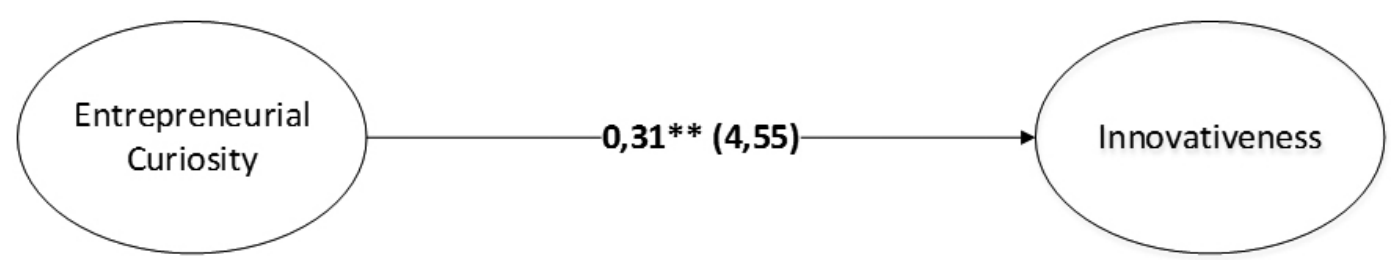

Figure 1: Standardized solution of the tested model and the T-values for the tested model

predisposition and fit the data. Confirmatory factor analysis (CFA) is generally used to test theory when the analyst has sufficiently strong rationale regarding what factors should be in the data and what variables should define each factor (Henson and Roberts, 2006).

According to the results from Figure 1 higher levels of entrepreneurial curiosity lead to higher levels of innovativeness; influence is moderate $(0.31)$, positive and statistically significant $(\mathrm{t}=4.55)$. This finding is in support of our hypothesis. The fit indices of the structural equation model present a good model fit, which is indicated by the values of $\chi^{2}=371,44$; $\mathrm{df}=118 ; \chi^{2} / \mathrm{df}=3,1478$; and RMSEA $=0.081$. The hypothesis was defined to test the relation between the constructs in this model; the relation show a statistical significance according to the t-test values whereas the whole model shows statistical significance of P-value $=0.0000$.

\section{Discussion}

An entrepreneur is the most important part of the whole entrepreneurship process. Entrepreneurs who are aware of being more innovative than other members of the same social system (e.g., other entrepreneurs) and count upon their innovativeness to face competition should re-organize their firms (Marcati, 2008). Since entrepreneurs with higher levels of entrepreneurial curiosity gather more data and knowledge, they should transform this base of applicable knowledge with innovativeness to better results of their companies.

Innovation is a broad term with multiple meanings; it draws on theories from a variety of disciplines and has been studied using a wide range of research methodologies (Crossan and Apaydin, 2010). In this research, the innovativeness is seen as the ability of entrepreneur to understand the meaning of the change and adaption. Thus, in relation with entrepreneurial curiosity an entrepreneur is capable to, not only understand but to incorporate innovativeness into the processes, business models and raise the level of innovativeness in whole organization. Since today, the change is the only constant entrepreneurs with high levels of entrepreneurial curiosity and innovativeness could be successful on the market by launching new products or services, explore and penetrate new markets and confront with the challenges on the global market competition.
The results of this study indicate that at the frame of entrepreneurship psychology entrepreneurial curiosity is important for innovativeness. This result is not surprising since already Price and Ridgway (1983) argued curiosity is one of the main components of the innovativeness.

\section{Contribution, implications for theo- ry, research, practice and econom- ic policy}

This study has some important implications for the literature of entrepreneurship. The ability to be innovative represents to entrepreneurs and their companies a relative advantage in relation to entrepreneurs that lack innovativeness. Baron and Tang (2011) argued relatively little direct evidence exists concerning mechanisms through which individual entrepreneurs encourage innovation in their companies. This paper presents the platform to identify entrepreneurs with higher level of entrepreneurial curiosity and innovativeness.

A primary implication of this paper is to facilitate future research on the field of entrepreneurship and more specifically on the field of entrepreneurial curiosity and innovativeness. The contribution of this paper is manifold. From the practical view of contribution policy makers can test individuals according to their level of entrepreneurial curiosity and innovativeness. Since both constructs have been linked to company's growth in the past it is logical to conclude that investing public money to certain nascent entrepreneurial actors who are identified as high on entrepreneurial curiosity and innovativeness level. A nascent entrepreneur is defined as a person who is now trying to start a new business, who expects to be the owner or part owner of the new firm, who has been active in trying to start the new firm in the past 12 months and whose start-up did not yet have a positive monthly cash flow that covers expenses and the owner-manager salaries for more than three month (Wagner, 2005). Another contribution of this paper from the practical view is ability of entrepreneurs to test employees. Those with higher levels of investigated constructs should be encouraged to the tasks demanding higher level of knowledge, inventiveness, and innovativeness. 
From the theoretical side I can argue that a literature gap on the field of entrepreneurial curiosity connected with innovativeness if fulfill. The structural equation model presented in this paper is the first model integrating these constructs and show that entrepreneurial curiosity positively influences innovativeness. Researchers will be able to test individuals in different countries and compare results with this study. Researchers will be able to test youth and transfer more entrepreneurial curious and innovative students to educational process that can offer them knowledge appropriate for entrepreneurship. According to that, this paper not just promotes entrepreneurship among youth but also stimulating youth to become active in entrepreneurship.

\section{Limitations and future research opportunities}

Although this research makes several important contributions, implications for theory, research, practice and economic policy, current results and conclusions regarding to impact on results of the enterprises are evaluated only within the theoretical frame. Based on the fact that this study has only theoretical implications for the growth of the company and consequently growth of the GDP regarding to entrepreneurial curiosity and innovativeness, future study should research the link to firm's growth in order to have an empirical conformation of that theoretical predisposition.

Another potential limitation of this study does not represent a problem for interpretation of the results, more it indicates opportunities for future research. For instance, the fact that the data were gathered among entrepreneurs in Slovenia and USA can indicate limitation, since it is not necessary that results would be equal in some Asian of African countries. Another research should include also entrepreneurs from those countries and also separate analysis for each country or groups of people depending on their demographics.

Psychological research of entrepreneurship has focused primarily on the founders - entrepreneurs rather than on employees of the organizations. Since also employees are important for the growth of the company and the fact that employees can be more entrepreneurial curious and innovative than the founders it would be interesting to develop new research addressing them and gather the data from that sample and thus compare the results with the results of entrepreneurs.

Entrepreneurial activity is recognized as a fundamental constituent of technological progress, business expansion, wealth creation and is considered as a major contributor to new job creation (Parker, 2004). Beside entrepreneurial curiosity and innovativeness also other factors influence the results of the company. Future study should include other factors not captured by the current research to develop a model with more constructs.

\section{Conclusion}

The findings of this study suggest that entrepreneurial curiosity and innovativeness are connected. Innovations by entrepreneurs tip the balance in the economy and lead to a process of creative destruction, via which firms that do not adopt the new technologies disappear (Soriano and Huarng, 2013). According to that, entrepreneurs should invent in their companies and stimulate innovative behavior among employees.

As indicated by these results, it seems that entrepreneurial curiosity and innovativeness are important constructs to forecast the growth of the company. Previous studies have focused primarily on the relations between entrepreneurial curiosity and other constructs (entrepreneurial self-efficacy, openness, firm growth) and innovativeness and other constructs (creativity, leadership, firm growth). This paper filled the literature gap on the related field of studied constructs and presents an important contribution for entrepreneurship theory.

\section{References}

Audi, R. (1993). Action, intention, and reason. Cornell University Press.

Bandalos, B. (1996). Confirmatory factor analysis. In J. Stevens (Ed.), Applied multivariate statistics for the social sciences (3rd ed., pp. 389-420). Mahwah, NJ: Lawrence Erlbaum.

Baron, R. A., \& Tang, J. (2011). The role of entrepreneurs in firm-level innovation: Joint effects of positive affect, creativity, and environmental dynamism. Journal of Business Venturing, 26(1), 49-60, http://dx.doi. org/10.1016/j.jbusvent.2009.06.002

Baron, R. A., Hmieleski, K. M., \& Henry, R. A. (2012). Entrepreneurs' dispositional positive affect: The potential benefits-and potential costs-of being "up". Journal of Business Venturing, 27(3), 310-324, http:// dx.doi.org/10.1016/j.jbusvent.2011.04.002

Bird, B. (1989). Entrepreneurial behavior. Glenview, IL: Scott Foresman.

Blume, B. D., \& Covin, J. G. (2011). Attributions to intuition in the venture founding process: Do entrepreneurs actually use intuition or just say that they do?.Journal of Business Venturing, 26(1), 137-151, http://dx.doi. org/10.1016/j.jbusvent.2009.04.002

Candemir, A., \& Zalluhoğlu, A. E. (2013). Exploring the Innovativeness and Market Orientation through Mission and Vision Statements: The Case of Istanbul Stock Exchange Companies. Procedia-Social and Behavioral Sciences, 99, 619-628, http://dx.doi.org/10.1016/j. 
sbspro.2013.10.532

Churchill, G. A., Jr. (1979). A paradigm for developing better measures of marketing constructs. Journal of marketing research, 16(1), 64-73, http://dx.doi. org $/ 10.2307 / 3150876$

Cope, J. (2005). Toward a dynamic learning perspective of entrepreneurship. Entrepreneurship Theory and Practice 29(4), 373-397, http://dx.doi.org/10.1111/j.15406520.2005.00090.x

Craig, J. B., Dibrell, C., \& Garrett, R. (2013). Examining relationships among family influence, family culture, flexible planning systems, innovativeness and firm performance. Journal of Family Business Strategy, In Press, Corrected Proof, http://dx.doi.org/10.1016/j. jfbs.2013.09.002

Crossan, M. M., \& Apaydin, M. (2010). A Multi-Dimensional Framework of Organizational Innovation: A Systematic Review of the Literature, Journal of Management Studies, 47(6), 1154-1191, http://dx.doi. org/10.1111/j.1467-6486.2009.00880.x

Dai, L., Maksimov, V., Gilbert, B. A., \& Fernhaber, S. A. (2013). Entrepreneurial orientation and international scope: The differential roles of innovativeness, proactiveness, and risk-taking. Journal of Business Venturing, In Press, Corrected Proof, http://dx.doi. org/10.1016/j.jbusvent.2013.07.004

Dawis, R. V. (1987). Scale construction. Journal of Counseling Psychology, 34(4), 481-489, http://dx.doi. org/10.1037//0022-0167.34.4.481

De Clercq, D., Sapienza, H.J., \& Crijns, H. (2005). The internationalization of small and medium-sized firms. Small Business Economics, 24(4), 409-419, http://dx. doi.org/10.1007/s11187-005-5333-x

Deniz, A., \& Godekmerdan, L. (2012). Determining Level of Students' technological Innovativeness: A Case Study. Procedia - Social and Behavioral Sciences, 47, 848-853, http://dx.doi.org/10.1016/j.sbspro.2012.06.746

Dess, G. G., \& Picken, J. C. (2000). Changing roles: Leadership in the 21st century. Organizational Dynamics, 28(3), 18-34, http://dx.doi.org/10.1016/S00902616(00)88447-8

DeVellis, R. F. (2003). Scale development: Theory and applications. Thousand Oaks, CA: Sage.

Dibrell, C., Craig, J. B., \& Neubaum, D. O. (2013). Linking the formal strategic planning process, planning flexibility, and innovativeness to firm performance. Journal of Business Research, In Press, Corrected Proof, http://dx.doi.org/10.1016/j.jbusres.2013.10.011

Edquist, C., Hommen, L., \& McKelvey, M. (2001). Innovation and employment: process versus product innovation, Northampton, MA: Edward Elgar Pub.

Fairlie, R. W., \& Holleran, W. (2012). Entrepreneurship training, risk aversion and other personality traits: Evidence from a random experiment. Journal of
Economic Psychology, 33(2), 366-378, http://dx.doi. org/10.1016/j.joep.2011.02.001

Gabor, D. (1970). Innovations: Scientific, technical and social. Oxford: The University Press.

Garcia, R., \& Calantone, R. (2002). A critical look at technological innovation typology and innovativeness terminology: a literature review. Journal of product innovation management, 19(2), 110-132, http://dx.doi. org/10.1111/1540-5885.1920110

Gerbing, D. W., \& Anderson, J. C. (1988). An updated paradigm for scale development incorporating unidimensionality and its assessment. Journal of Marketing Research, 25(2), 186-192.

Grundström, C., Öberg, C., \& Öhrwall Rönnbäck, A. (2012). Family-owned manufacturing SMEs and innovativeness: A comparison between within-family successions and external takeovers. Journal of family business strategy, 3(3), 162-173, http://dx.doi. org/10.1016/j.jfbs.2012.07.001

Henson, R. K., \& Roberts, J. K. (2006). Use of exploratory factor analysis in published research common errors and some comment on improved practice. Educational and Psychological measurement, 66(3), 393-416, http://dx.doi.org/10.1177/0013164405282485

Hinkin, T. R. (1995). A review of scale development practices in the study of organizations. Journal of Management, 21(5), 967-988, http://dx.doi. org $/ 10.1177 / 014920639502100509$

Huarng, K. H., \& Ribeiro-Soriano, D. E. (2014). Developmental management: Theories, methods, and applications in entrepreneurship, innovation, and sensemaking. Journal of Business Research, 67(5), (657-662), http://dx.doi.org/10.1016/j.jbusres.2013.11.023

Hurley, R. F., \& Hult, G. T. M. (1998). Innovation, market orientation, and organizational learning: An integration and empirical examination. Journal of Marketing, 62(3), 42-54.

Jackson, D.N. (1994). Jackson Personality InventoryRevised Manual. Port Heron, MI: Sigma Assessment Systems, Inc.

Jeraj, M. \& Antončič, B. (2013). A Conceptualization of Entrepreneurial Curiosity and Construct Development: a Multi-Country Empirical Validation. Creativity Research Journal, 25(4), 426-435, http://dx.doi.org/10.1 $\underline{080 / 10400419.2013 .843350}$

Jeraj, M. \& Marič, M. (2013a). Relation between Entrepreneurial Curiosity and Entrepreneurial Self-efficacy: a Multi-Country Empirical Validation. Organizacija, 46(6), 264-273, http://dx.doi.org/10.2478/orga-2013$\underline{0027}$

Jeraj, M. \& Marič, M. (2013b). Entrepreneurial Curiosity - The New Construct. High potentials, lean organization, internet of things: proceedings of the 32nd International Conference on Organizational Science Development (str. 289-298). Kranj: Moderna organizacija. 
Jeraj, M. \& Prodan, I. (2010). Conceptualization of Entrepreneurial Curiosity. Paper presented at the Advances in Business-Related Scientific Research Conference 2010: Olbia, Italy.

Jeraj, M. (2012). Toward the new construct; Entrepreneurial Curiosity. V D. Barkovic and B. Runzheimer (ur.), Interdisciplinary research VIII (p. 1043-1055). Opatija: Josip Juraj Strossmayer University in Osijek.

Jeraj, M. (2014). Entrepreneurial Curiosity: Construct Development, Determinants and Outcomes. Doctoral Dissertation. University of Ljubljana: Faculty of Economics.

Kardos, M. (2012). The Relationship between Entrepreneurship, Innovation and Sustainable Development. Research on European Union Countries. Procedia Economics and Finance, 3, 1030-1035, http://dx.doi. org/ 10.1016/S2212-5671(12)00269-9

Kosec, K., \& Miglič, G. (2012). Vpliv zunanjih in notranjih dejavnikov na individualno uspešnost prodajalca - primer družbe Relax Turizem. Organizacija, 45(4), A116-A123.

Krueger Jr, N. F. (2003). The cognitive psychology of entrepreneurship. In Handbook of entrepreneurship research (pp. 105-140). Springer US.

Likert, R. (1974). A method of constructing an attitude scale. Scaling: A sourcebook for behavioral scientists, 21-43.

Lumpkin, G. T., \& Dess, G. (1996). Clarifying the entrepreneurial orientation construct and linking it to performance. Academy of Management Review, 21(1), 135-172, http://dx.doi.org/10.5465/ AMR.1996.9602161568

Marcati, A., Guido, G., \& Peluso, A. M. (2008). The role of SME entrepreneurs' innovativeness and personality in the adoption of innovations. Research Policy, 37(9), 1579-1590, http://dx.doi.org/10.1016/j.respol.2008.06.004

Markman, G. D., \& Baron, R. A. (2003). Person-entrepreneurship fit: why some people are more successful as entrepreneurs than others. Human resource management review, 13(2), 281-301, http://dx.doi. org/10.1016/S1053-4822(03)00018-4

Mueller, S. L., \& Thomas, A. S. (2001). Culture and entrepreneurial potential: A nine country study of locus of control and innovativeness. Journal of business venturing, 16(1), 51-75, http://dx.doi.org.ezproxy.lib.ukm. si/10.1016/S0883-9026(99)00039-7

OECD. (2010). SMEs, Entrepreneurship and Innovation, Series: OECD Studies on SMEs and Entrepreneurship.

Parker, S. C. (2004). The economics of self-employment and entrepreneurship. Cambridge, UK: Cambridge University Press.

Parker, S. C. (2013). Do serial entrepreneurs run successively better-performing businesses?. Journal of Business Venturing, 28(5), 652-666, http://dx.doi. org/10.1016/j.jbusvent.2012.08.001

Price, L. L., \& Ridgway, N. M. (1983). Development of a scale to measure use innovativeness. Advances in consumer research, 10(1), 679-684.

Rae, D., \& Carswell, M. (2000). Using a life-story approach in researching entrepreneurial learning: the development of a conceptual model and its implications in the design of learning experiences. Education and Training, 42(4/5), 220-227, http://dx.doi.org/ $10.1108 / 00400910010373660$

Rezaei, J., Ortt, R., \& Scholten, V. (2012). Measuring entrepreneurship: Expert-based vs. data-based methodologies. Expert Systems with Applications, 39(4), 40634074, http://dx.doi.org/10.1016/j.eswa.2011.09.091

Sanchez-Franco, M. J., \& Roldán, J. L. (2010). Expressive aesthetics to ease perceived community support: Exploring personal innovativeness and routinised behaviour as moderators in Tuenti. Computers in Human Behavior, 26(6), 1445-1457, http://dx.doi.org/10.1016/j. chb.2010.04.023

Savalei, V., \& Bentler, P. M. (2010). Structural equation modeling. Corsini Encyclopedia of Psychology, John Wiley \& Sons, Inc. http://dx.doi. org/10.1002/9780470479216.corpsy0953

Schmelter, R., Mauer, R., Börsch, C., \& Brettel, M. (2010). Boosting corporate entrepreneurship through HRM practices: Evidence from German SMEs. Human Resource Management, 49(4), 715-741, http://dx.doi. org/10.1002/hrm.20366

Schumpeter, J.A. (1934). The theory of economic development. Cambridge, MA: Harvard Press.

Soriano, D. R., \& Huarng, K. H. (2013). Innovation and entrepreneurship in knowledge industries. Journal of Business Research, 66(10), 1964-1969, http://dx.doi. org/10.1016/j.jbusres.2013.02.019

Tajeddini, K., \& Trueman, M. (2008). Effect of customer orientation and innovativeness on business performance: a study of small-sized service retailers. International Journal of Entrepreneurship and Small Business, 6(2), 280-295. http://dx.doi.org/10.1504/ IJESB.2008.018633

Tidd, J., \& Bessant, J. (2011). Managing innovation: integrating technological, market and organizational change. John Wiley \& Sons.

Türker, M. V., \& İnel, M. N. (2012). The effect of locus of control orientation on perceived individual innovativeness: An empirical research in Turkey. Procedia-Social and Behavioral Sciences, 58, 879-888, http://dx.doi. org/10.1016/j.sbspro.2012.09.1066

Tushman, M. L., \& O’Reilly III, C. A. (1996). Ambidextrous organizations: managing evolutionary and revolutionary change. California management review, 38(4), 8-30.

Ünay, F. G., \& Zehir, C. (2012). Innovation intelligence and entrepreneurship in the fashion industry. Pro- 
cedia-Social and Behavioral Sciences, 41, 315-321, http://dx.doi.org/10.1016/j.sbspro.2012.04.036

Uray, N., \& Dedeoglu, D. (1997). Identifying fashion clothing innovators by Self-Report method. Journal of Euro-Marketing, 6(3), 27-46, http://dx.doi. org/10.1300/J037v06n03 02

Venkatraman, P. M. (1991). The impact of innovativeness and innovation type and adoption. Journal of Retailing, 67(1), 51-67.

Wagner, J. (2005). Nascent and infant entrepreneurs in Germany: Evidence from the regional entrepreneurship monitor (REM) (No. 1). University of Lüneburg working paper series in economics.

Yu, Y., Dong, X. Y., Shen, K. N., Khalifa, M., \& Hao, J. X. (2013). Strategies, technologies, and organizational learning for developing organizational innovativeness in emerging economies. Journal of Business Research, 66(12), 2507-2514, http://dx.doi.org/10.1016/j.jbusres.2013.05.042

Zhang, X., Ma, X., \& Wang, Y. (2012). Entrepreneurial orientation, social capital, and the internationalization of SMES: evidence from China. Thunderbird International Business Review, 54(2),195-210, http://dx.doi. org/10.1002/tie.21451

Zhou, L. (2007). The effects of entrepreneurial proclivity and foreign market knowledge on early internationalization. Journal of World Business, 42(3), 281-293, http://dx.doi.org/10.1016/j.jwb.2007.04.009

Žiga Peljko, is a Ph.D. student at University of Primorska, Faculty of Management, Koper, Slovenia, and a researcher on the field of management and entrepreneurship. He has authored, co-authored and present papers on conferences and published papers in different journals. His bibliography includes over 100 papers from the field of investments, stock exchange issues, mutual funds, and related fields. Beside he is a lecturer at GEA College, Ljubljana Slovenia and Univerzitet Donja Gorica in Monte Negro. He is a Head of investments at KD Group d.d. for abroad and a member of different Slovenian and regional Management Boards and Supervisory Boards.
Mitja Jeraj, Ph.D., is a researcher on the field of entrepreneurship, management, and organizational sciences. His main research interests include entrepreneurship as a broad field of research, entrepreneurial curiosity and other entrepreneurial personalities, relations between entrepreneurship and economic growth, relations between entrepreneurship and unemployment, connection between entrepreneurship and development of sport etc. His research focuses also on management at small and medium enterprises, on cost management and on development of the organization over the time. He has authored and co-authored and present papers on conferences and published papers in scientific journals.

Gheorghe Savoiu, Ph.D., is a professor at the University of Pitesti, Faculty of Economic Sciences at the Department of Finance, and Accounting, Romania. His main research interests include economics, statistics, econometrics, demographics, entrepreneurial economics, labor statistics, macroeconomics, projects with foreign financing and econophysics. He is the editor of several high-ranking journals. He is a member and vice-president of the Romanian statistical society and the chief of the Romanian school of physical socioeconomics. He has authored and co-authored many books and presented papers on conferences and published papers in scientific journals. He has also participated in research projects and consulting work.

Miha Marič, Ph.D., is a researcher in the area of leadership, management, and organizational sciences. He is currently employed as an assistant professor at the University of Maribor's Faculty of Organizational Sciences and has a Ph.D. from the Faculty of Economics, University of Ljubljana. His research interests are power, leadership, organizational behavior, HRM, management, organization. As author or co-author, he has published twenty original scientific articles, thirteen professional articles, thirty-five scientific conference contributions, two chapters in monographs and co-authored one scientific monograph, and been an editor and reviewer. He has also participated in research projects and consulting work. 


\section{Empirična raziskava povezanosti med podjetniško radovednostjo in inovativnostjo}

Ozadje in namen: Kljub akademskemu zanimanju za razumevanje vlog različnih dejavnikov na podjetnike in njihovo vedenje, je malo znanega o povezanosti med podjetniško radovednostjo in inovativnostjo. Ta raziskava raziskuje povezanost med podjetniško radovednostjo, ki motivira podjetnike za zbiranje informacij o svojem poslovanju in inovativnosti, ki motivira podjetnike k vključitvi inovacij v podjetniške procese.

Oblikovanje / Metodologija / Pristop: Udeleženci v tej raziskavi, so bili podjetniki iz Slovenije in ZDA. Z uporabo modeliranja strukturnih enačb smo povezali dva konstrukta, podjetniško radovednost in inovativnost za preverjanje vpliva.

Rezultati: Rezultati prikažejo, da podjetniška radovednost pozitivno vpliva na inovativnost. Rezultati te raziskave prikažejo, da je v okviru podjetniške psihologije podjetniška radovednost pomembna za inovativnost.

Zaključek: Članek povezuje dva preučevana konstrukta in predstavlja dragocen prispevek za teorijo podjetništva; zato se lahko rezultati uporabijo za nadaljnje znanstvene raziskave, kakor tudi za praktične implikacije.

Ključne besede: podjetniška radovednost; inovativnost; podjetje; podjetništvo; podjetnik 